\title{
The Role of Foreign Directors in Corporate Risk Disclosure: Empirical Evidence From Jordan
}

\author{
Malek Hamed Alshirah ${ }^{1}$, Azhar Abdul Rahman ${ }^{1} \&$ Ifa Rizad Mustapa ${ }^{1}$ \\ ${ }^{1}$ School of Accountancy, College of Business, Universiti Utara Malaysia, Sintok, Malaysia \\ Correspondence: Malek Hamed Alshirah, School of Accountancy, College of Business, Universiti Utara Malaysia, \\ Sintok, Malaysia. Tel: 60-17-947-3592.
}

Received: June 4, 2019

doi:10.5430/ijfr.v10n4p119
Accepted: July 7, 2019

Online Published: July 21, 2019

URL: https://doi.org/10.5430/ijfr.v10n4p119

\begin{abstract}
The current study examined the role of foreign directors in enhancing the level of risk disclosure in the annual reports of Jordanian listed companies. The content analysis method was used to measure the level of risk disclosure by computing the number of risk-related sentences in annual reports. To achieve the study's objective, random effect model has been applied on a sample of 376 firm-year observations of Jordanian non-financial companies for the period of 2014-2017. The findings are in line with the argument of agency theory and resource dependence theory, which posits that existence of foreign members on the board contributes in increasing the level of risk disclosure. The study aimed to fill the gap in the literature of risk disclosure regarding the relationship between foreign directors and risk disclosure. It is expected that the findings will be useful to researchers, authorities and investors alike in understanding the important role of foreign directors in improving practices of risk disclosure in Jordan.
\end{abstract}

Keywords: risk disclosure, foreign directors, content analysis, Jordan

\section{Introduction}

Global financial crises and major corporate collapses have rekindled the debate about the importance of including risk information in financial reports. This is attributed to the needs of stakeholders for valuable relevant information about companies' activities in order to accurately assess their financial position (Uddin \& Hassan 2011; Zeghal \& Aoun, 2016). As a response to those global events, regulatory institutions had to reassess the foundations of companies' regulations (ElKelish \& Hassan, 2014; Beltratti \& Stulz, 2012). Risk disclosure allows outside investors to analyze the company's current risks and judge future prospects to have a clear picture of the future risk that the company may face (Linsley \& Shrives, 2006). Furthermore, risk disclosure contributes in improving investment efficiency by reducing agency problem and mitigating information asymmetry between investors and managers, and helps them to make sound investment decisions ( $\mathrm{Li}, \mathrm{He}, \&$ Xiao, 2018).

Foreign members have a unique understanding and knowledge of outside markets' strategies that a firm wants. Thus, such knowledge may contribute additional value to the intended expansion of the company (Dewayanto, Kurniawanto, Suhardjanto, \& Honggowati, 2017). Additionally, foreign directors have been evidenced to enhance the board's independence (Carter, Simkins, \& Simpson, 2003). According to Miletkov, Poulsen and Wintoki (2017), foreign directors are expected to be related with firms having a limited number of qualified local directors, and these include firms in countries that are characterized by a smaller population, low level of education and lower capital market development. International boards are considered as an effective mechanism to transfer governance across countries. Companies are also introduced to corporate governance characteristics and board of director's practices of foreign companies through their foreign directors' experiences (Iliev \& Roth, 2018).

Jordan is considered one of the most important Arab countries that attract foreign investment. Jordan undertook a number of reforms aimed to liberalize foreign investments in the 1970s. Additionally, due to Lebanon's civil war in the 1970s, Jordan replaced Lebanon as the financial center of the Middle East. Hence, many companies and businesses shifted their operations to Jordan (Al-Akra \& Ali, 2012). Nevertheless, The United Nations Conference on Trade and Development (UNCTAD) indicated that hazards such as a high level of risk and uncertainties surrounding foreign investments in Jordan (Al-tamimi, 2017). Foreign members serving on board of directors can help in assuring foreign investors that a firm is managed effectively and with the investors' best interests as evidenced by the pressure placed on companies to reveal important information (including risk information) 
(Dewayanto et al., 2017; Oxelheim \& Randøy, 2003). Accordingly, the Jordanian situation is more attractive to study the effect of foreign director's role on the level of risk information disclosed by management. The potential effect of foreign directors on the level of risk disclosure has been neglected in prior studies. Therefore, the present study examined the role of foreign directors in improving risk disclosure practices in Jordanian non-financial firms.

\section{Literature Review and Hypothesis Development}

When the company appoints foreign members in its board, this conveys a good impression to foreign investors as a guarantee of good corporate governance practices (Abdullah, Chizema, \& Chandren, 2016). In the same vein, Miletkov et al. (2017) also found a positive association between firm performances in countries having lower-quality legal environments and meanwhile they have directors hailed from a country having relatively greater quality legal environments than those of the host country. Added to the above studies, Tsang, Xie and Xin (2019) found that foreign institutional investors improve corporate disclosure more than local investors, particularly when foreign institutional investors come from nations having high disclosure requirements and investor protection. Ujunwa (2012) revealed that board nationality affects firm performance positively. Likewise, Oxelheim and Randøy (2003) indicated that firms' higher value was significantly related to the proportion of foreign board's members. In related studies, Du, Jian and Lai (2017), Jackson (2017) and Wu, Shen and Lu (2015) indicated that the existence of foreign directors on the board helps in mitigating earnings management practices and enhancing earnings quality. Furthermore, Ibrahim and Hanefah (2016) and Khan (2010) investigated the level of corporate social responsibility disclosure. They revealed that foreign directors had significant positive effect on CSR disclosure. Makhlouf, Al-Sufy and Almubaideen (2018) found foreign directors to be positively related with accounting conservatism in Jordan.

In contrast, some other studies in the topic did not support the assumption that foreign shareholders are better than their domestic counterparts in performing their duties effectively. To begin with, Barako and Brown (2008) revealed that the existence of foreign directors on the board had an insignificant effect on voluntary disclosure. They argued that foreign directors on the board probably support the interest of foreign owners and as such, their presence on the board may serve as a substitutive way to access wanted information rather than improved disclosure practices. Also, foreign director is more likely to have less effective monitoring role on management than local director, consequently reducing the effectiveness of the board in respect to its monitoring and disciplining functions (Masulis, Wang, \& Xie, 2012).

In a nutshell, in light of the above-mentioned literature, it is clear that only few prior studies have investigated the association between foreign directors and disclosure, and their results are mixed and inconclusive. Hence, the link between the two variables still needs confirmation. Moreover, to the best of the author's knowledge of the available literature, corporate risk disclosure has yet to receive extensive focus and attention. Thus, more studies are required to identify the relationship between foreign directors and disclosure, especially in risk disclosure context. Therefore, the current study is among the first to fill this literature gap.

Based on the agency theory, foreign directors have a role in monitoring management effectively by exploiting their positions as representatives on behalf of foreign investors to militate against manager's interests. Foreign directors offer a mechanism to halt the negative impact of managers (Dewayanto et al., 2017). In addition, resource dependence theory views foreign members of a board as strategic resources, who facilitate the access to available external input. Hence, resource dependence theory favors skilled foreign directors to provide good connection with the external environments (Ujunwa, 2012). Furthermore, as foreign directors have a broad range of international connections with foreign stakeholders, they are expected to provide higher level of transparency and disclosure (Ibrahim \& Hanefah, 2016).Therefore, based on agency theory, resource dependence theory and the discussion above, the expectation is that the presence of foreign directors is positively related to the level of risk disclosure. The following hypothesis is formulated:

$H$ : There is a positive relationship between foreign directors and the level of risk disclosure.

\section{Research Design}

\subsection{Sample and Data Collection}

The sample of this study is Jordanian listed companies because they are considered the most important sources that contribute in an increase of GDP in Jordan (ASE, 2017; Moumen, Ben Othman, \& Hussainey, 2016). Where, the total market value of them represented 83\% of Jordan's GDP in 2017 (ASE, 2017). Eleven (11) firms were excluded given their data unavailability and other constraints. Moreover, firms in the financial sector were excluded as they have different codes of corporate governance and apply specific disclosure requirements (Al-Akra, Ali, \& Marashdeh, 2009). 


\subsection{Method}

The present study adopted content analysis as it aims to examine the level/nature of disclosure regardless of the quality of corporate risk disclosures (Amran, Bin \& Hassan, 2009; Elzahar \& Hussainey, 2012; Linsley \& Shrives, 2006). Additionally, the current study used sentences as a coding unit because while a word is the smallest unit in a sentence, it cannot convey an idea or message clearly (Ivers, 1991; Linsley \& Shrives, 2006). Moreover, using a sentence as coding units helps in avoiding the double-counting of the same sentence even if that sentence includes more than one word referring to risk disclosure (Elzahar \& Hussainey, 2012).This study adopted the broad definition of Linsley and Shrives (2006) to identify the risk-related sentences which inform the reader if "any opportunity or prospect, or of any hazard, danger, harm, threat or exposure, has already impacted upon the company or may impact upon the company in the future or of the management of any such opportunity, prospect, hazard, harm, threat or exposure" (Linsley \& Shrives, 2006, p.388).

This current study adopted and replicated a set of decision rules which developed by Linsley and Shrives (2006) and Konishi and Ali (2007) (see Appendix B) to clarify the content analysis procedures and ensure the reliability of measurement and reduce variation of the results by distinguishing the risk information in the annual reports from other. Moreover, this study employed risk categories proposed by Linsley and Shrives's (2006) model comprising of financial risk, operation risk, empowerment risk, information processing and technology risk, integrity risk and strategic risk (see Appendix A). Finally, this study calculated a final risk disclosure score for each firm by gathering the number of risk-related sentences existing in the annual reports of Jordanian firms (Elzahar \& Hussainey, 2012).

To ensure the validity and reliability of the adopted coding method, a single coder, who is an expert in the field and who is familiar with the content analysis method, reviewed and coded risk-related sentences that exist in the pilot study independently, which consisted of 40 firms, constituting $10.63 \%$ from the total 376 annual reports. Afterwards, the results of the two coders (the researcher and the coder) were compared to determine the level of consistency in applying rules, since the measurement is considered as reliable if other researchers replicate the same measurement and get the same results (Marston \& Shrives, 1991). To verify the reliability of the measurement, Cronbach's Alpha was applied as a statistical test, and the obtained result is $83.2 \%$, indicating high internal consistency between the outputs of both coders with no significant differences between them. Hence, content analysis method can be considered as a reliable measurement of risk information that are disclosed by Jordanian listed firms.

This study used multiple regression analysis model to investigate the influence of foreign directors on the level of corporate risk disclosure. Table 1 also contains some control variables used in this study.

$$
\mathrm{CRD}=\beta_{0}+\beta_{1} \text { FORD }_{\mathrm{it}+} \beta_{2} \mathrm{SIZE}_{\mathrm{it}}+\beta_{3} \mathrm{SECTR}_{\mathrm{it}}+\beta_{4} \mathrm{LEVER}_{\mathrm{it}}+\varepsilon_{\text {it }}
$$

Table 1. Measurement of variables

\begin{tabular}{lll}
\hline Acronym & Variables & Measurement \\
\hline CRD & $\begin{array}{l}\text { Corporate } \\
\text { Disclosure }\end{array}$ & $\begin{array}{l}\text { Measured by number of risk-related sentences existing in the } \\
\text { annual reports of Jordanian companies. }\end{array}$ \\
\hline FORD & $\begin{array}{l}\text { Foreign } \\
\text { Directors }\end{array}$ & $\begin{array}{l}\text { Measured by dummy variable, } 1 \text { if the firm has at least one } \\
\text { foreign director and 0 otherwise. }\end{array}$ \\
\hline SIZE & Company Size & Measured by natural log of total assets. \\
\hline SECTR & Type of Sector & $\begin{array}{l}\text { Classified into industrial or services sector, measured by } \\
\text { dummy variable, } 1 \text { if companies belong to an industrial sector, } \\
\text { 0 otherwise. }\end{array}$ \\
\hline LEVER & Leverage & Measured by total debt to total assets. \\
\hline
\end{tabular}

\section{Results and Discussion}

\subsection{Descriptive Statistics of Variables}

Table 2 shows the descriptive statistics for total risk-related sentences in 94 Jordanian firms' annual reports over the period from 2014-2017. All risk-related sentences were categorized through one of six risk categories and computed as shown in Table 2. The total number of risk disclosure sentences is 10,660 sentences in all the annual reports of 
Jordanian firms. Total risk disclosure sentences for each firm ranged from a minimum value of 2 sentences to a maximum value of 61 sentences, with a mean value of 28 sentences.

Table 2. Descriptive statistics of risk disclosure

\begin{tabular}{lllllll}
\hline Risk Disclosure & Sum & Mean & Min & Max & $\begin{array}{l}\text { No. of Risk } \\
\text { Sentences }\end{array}$ & Percentage \\
\hline Financial Risk & 3090 & 8.218085 & 0 & 22 & 3090 & $29 \%$ \\
\hline Operation Risk & 2376 & 6.319149 & 0 & 14 & 2376 & $22 \%$ \\
\hline $\begin{array}{l}\text { Empowerment } \\
\text { Risk }\end{array}$ & 969 & 2.577128 & 0 & 10 & 969 & $9 \%$ \\
\hline $\begin{array}{l}\text { Information P \& } \\
\text { T Risk }\end{array}$ & 836 & 2.223404 & 0 & 14 & 836 & $8 \%$ \\
\hline $\begin{array}{l}\text { Integrity Risk } \\
\text { Strategic Risk }\end{array}$ & 22165 & 3.098404 & 0 & 11 & 1165 & $11 \%$ \\
\hline $\begin{array}{l}\text { Total Risk } \\
\text { Disclosure }\end{array}$ & 10660 & 28.898936 & 0 & 20 & 2218 & $21 \%$ \\
\hline
\end{tabular}

The descriptive statistics for independent and control variables are shown in Table 3 . The average of foreign directors (FORD), who serving on the board of directors in Jordanian companies, is 32.45\%. Regarding control variables, Table 3 shows that the average firm size (SIZE) is 7.479. As for type of sector, the the percentage of industrial sector (SECTR) is $52.13 \%$, indicating that more than half of Jordanian firms are in industrial firms. The mean value of leverage (LEVER) is $32.273 \%$.

Table 3. Descriptive statistics for all variables

\begin{tabular}{llllll}
\hline Variable & Obs & Mean & Std.Dev. & Min & Max \\
\hline FORD & 376 & .324 & .469 & 0 & 1 \\
\hline SIZE & 376 & 7.479 & .639 & 5.861 & 9.255 \\
\hline SECTR & 376 & .521 & .5 & 0 & 1 \\
\hline LEVER & 376 & 32.273 & 23.024 & 0 & 104 \\
\hline
\end{tabular}

\subsection{Diagnostic Tests}

Several tests must be conducted to verify the quality of the data panel. In this study, multicollinearity was tested by the correlations matrix test as shown in Table 4 . All variables have correlation of less than 0.477 , which means there is no multicollinearity, because none of the variables correlated above 0.9 .

Table 4. Correlations matrix of study variables

\begin{tabular}{|c|c|c|c|c|c|}
\hline Variables & CRD & FORD & SIZE & SECTR & LEVER \\
\hline (1) CRD & 1.000 & & & & \\
\hline (2) FORD & $0.2476 * * *$ & 1.000 & & & \\
\hline (3) SIZE & $0.300 * * *$ & $0.1388 * * *$ & 1.000 & & \\
\hline (4) SECTR & $0.202 * * *$ & 0.0728 & $-0.120 * *$ & 1.000 & \\
\hline (5) LEVER & $0.258 * * *$ & -0.0584 & $0.390 * * *$ & 0.026 & 1.000 \\
\hline
\end{tabular}


This study used Breusch Pagan test to examine the presence of heteroscedasticity problem. In addition, the Wooldridge test was conducted to detect whether the autocorrelation problem existed or not. The Breusch Pagan test showed an insignificant p-value $(0.1895>0.05)$. Consequently, the heteroscedasticity problem was confirmed to be non-existent in the study data. Additionally, the result of Wooldridge test also showed insignificant p-value (0.0707> 0.05). This indicates that the autocorrelation problem did not exist in the study data. In order to determine the appropriate model to the study, some tests were conducted. Lagrange Multiplier test (LM) assisted in selecting between random effect model and pooled OLS model. The result of LM test was significant $(0.000<0.05)$. Thereby, using random effects was deemed to be suitable for the study (Gujarati \& Porter, 2012). The Hausman specification test was used to select between fixed model and random model. Hausman test obtained an insignificant result $(0.0664>0.05)$. Hence, it could be concluded that RE model is opted to analyze the data.

\subsection{Regression Analysis Results}

The model was estimated by using random effect method. Table 5 shows the findings of the relationship between dependent variable (corporate risk disclosure), independent variable (foreign directors) and control variables (firm size, leverage and sector type). The model is statistically significant and fit at the $1 \%$ level with the $\mathrm{p}$-value $=0.000$. $\mathrm{R}^{2}=0.344$.

As shown in Table 5, there is a significant positive relationship between foreign directors (FORD) and risk disclosure $(\mathrm{CRD})(\mathrm{t}=1.80, \mathrm{P}=0.071)$. This result indicates that foreign directors, who serve on the board of directors, have significant positive effect on the level of risk disclosure and enhanced quality of financial reports. This result is consistent with the findings of the previous studies and with the view of resource dependence theory that proposes foreign members of a board as outside strategic resources, who facilitate the access to available external input and provide connections with a firm's external environment (Ujunwa, 2012). The result is in line with Dewayanto et al. (2017) and Tsang et al. (2019) who found that foreign investors help in the improvement of corporate disclosure. Likewise, Jackson (2017), Oxelheim and Randøy (2003) and Wu et al. (2015) indicated that the presence of more foreign investors enhanced firm value and earnings quality and mitigated earnings management. Khan (2010) found foreign directors to have a positive effect on the level of corporate social responsibility disclosure. In addition, Ibrahim and Hanefah (2016) and Makhlouf et al. (2018) found foreign directors to be positively related with the CSR disclosure and accounting conservatism, respectively in Jordan.

Table 5. Multiple regression results

\begin{tabular}{llllll}
\hline CRD & Coef. & Predict sign & t-value & p-value & Sig \\
\hline FORD & 2.837 & + & 1.80 & 0.071 & $*$ \\
\hline SIZE & 1.640 & $+/-$ & 1.22 & 0.222 & \\
\hline SECTR & 4.057 & $+/-$ & 2.36 & 0.018 & $* *$ \\
\hline LEVER & 0.018 & $+/-$ & 0.67 & 0.501 & \\
\hline Number of Obs & 376 & & & & \\
\hline R- Squared & 0.344 & & & & \\
\hline Prob $>$ Chi2 & 0.000 & & & & \\
\hline$* * * \mathrm{p}<0.01, * * \mathrm{p}<0.05, * \mathrm{p}<0.1$ & & & & & \\
\hline
\end{tabular}

The relationship between firm size (SIZE) and corporate risk disclosure (CRD) is insignificantly positive ( $\mathrm{t}=1.22, \mathrm{p}$ $=0.222$ ). These findings suggest that firm size does not affect the level of risk disclosure in Jordanian companies. This result is in line with Hassan (2009), who revealed an insignificant association between the two variables. Table 5 shows a significant positive relationship between type of sector (SECTR) and corporate risk disclosure (CRD) $(t=$ 2.36, $\mathrm{p}=0.018$ ), suggesting that firms in the industrial sector disclose risk information more than those in the service sector. This result is consistent with Rajab and Handley-Schachler (2009), who revealed that industry type was significantly and positively related to the risk information that companies disclose. Moreover, leverage of firms (LEVER) has an insignificant association with corporate risk disclosure (CRD) $(t=0.67, p=0.501)$. This result indicates that leverage does not affect the level of risk disclosure. This result is similar to previous studies of Linsley 
and Shrives (2006), Abraham and Cox (2007) and Elzahar and Hussainey (2012), who found an insignificant relationship between leverage and risk disclosure.

\section{Conclusion and Limitation}

\subsection{Conclusion}

The main purpose of the paper is to examine the effect of foreign directors on level of risk disclosure of non-financial Jordanian listed firms. The current research provides a contribution to the literature of risk disclosure by documenting that the foreign directors can improve the transparency of financial reporting by exploiting their experience to control the financial reporting processes. The study examined a sample of 94 Jordanian listed firms' annual reports in the four-year period from 2014 to 2017. Content analysis method has been used to compute the number of risk-related sentences. Total of risk disclosure sentences to each firm ranges from a minimum value of 2 sentences to a maximum value of 61 sentences and the mean of RD is 28 sentences. Also, random effect method is employed for the empirical analysis. The findings show that the existence of foreign directors on the board is positively related with the level of risk disclosure. The results refer to the practical implication of the foreign directors in increasing the level of risk disclosure in Jordanian listed firms. Thereby, policymakers should consider such characteristic of the board of directors to benefit from the capabilities of foreign directors in improving their monitoring role and enhance the amount of risk information.

\subsection{Limitations and Suggestions}

This study has added more understanding to the nature of the relationship between foreign directors and corporate risk disclosure practices. However, the study has several limitations. Therefore, this study can be extended in future research in several ways to overcome its limitations as follows.

This study focuses on the effect of foreign directors on corporate risk disclosure. Therefore, future empirical researches are advised to consider other board diversity variables namely, age, gender, ethnic, etc. This study focused on the factors that probably influence the level of risk disclosure and ignored the outcomes of risk disclosure practices. Further research could be conducted to investigate the consequences of risk disclosure (e.g., cost of capital, analysts' forecast, firm value and share prices). Further, the period of study restricted to cover only four years (from 2014 to 2017), which may not be generalized for other before-and-after periods.

\section{References}

Abdullah, Z., Chizema, A., \& Chandren, S. (2016). The relationship between Malaysian directors and foreign equity ownership: An institutional approach. Paper Presented at the International Conference on Accounting Studies $(I C A S)$. Retrieved from www.icas.my

Abraham, S., \& Cox, P. (2007). Analysing the determinants of narrative risk information in UK FTSE 100 annual reports. The British Accounting Review, 39, 227-248. https://doi.org/10.1016/j.bar.2007.06.002

Al-Akra, M., \& Ali, M. J. (2012). The value relevance of corporate voluntary disclosure in the Middle-East: The case of Jordan. Journal of Accounting and Public Policy, 31(5), 533-549. https://doi.org/10.1016/j.jaccpubpol.2011.10.007

Al-Akra, M., Jahangir Ali, M., \& Marashdeh, O. (2009). Development of accounting regulation in Jordan. International Journal of Accounting, 44(2), 163-186. https://doi.org/10.1016/j.intacc.2009.03.003

Al-Shammari, B. (2014a). An investigation of the impact of corporate governance mechanisms on level of corporate risk disclosure: Evidence from Kuwait. International Journal of Business and Social Research, 4(6), 51-70.

Al-Tamimi, F. (2017, June 11). \$ 10.6 billion foreign investments in Jordan within 6 years. Al Rai Newspaper.

Amran, A., Bin, A., \& Hassan, B. (2009). Risk reporting: An exploratory study of risk management disclosure in Malaysian annual reports. Managerial Auditing Journal, 24(1), 39-57. https://doi.org/10.1108/02686900910919893

Barako, D. G., \& Brown, A. M. (2008). Corporate social reporting and board representation: evidence from the Kenyan banking sector. Journal of Management and Governance, 12(4), 309-324. https://doi.org/10.1007/s10997-008-9053-x

Beltratti, A., \& Stulz, R. M. (2012). The credit crisis around the globe: Why did some banks perform better? Journal of Financial Economics, 105(1), 1-17. https://doi.org/10.1016/j.jfineco.2011.12.005 
Carter, D. A., Simkins, B. J., \& Simpson, W. G. (2003). Corporate governance, board diversity, and value. The Financial Review, 38(1), 33-53. https://doi.org/10.1111/1540-6288.00034

Dewayanto, T., Kurniawanto, H., Suhardjanto, D., \& Honggowati, S. (2017). Audit committee toward internal control disclosure with the existence of foreign directors as moderation variable. Review of Integrative Business and Economics Research, 6(3), 324-332.

Du, X., Jian, W., \& Lai, S. (2017). Do foreign directors mitigate earnings management? Evidence from China. The International Journal of Accounting, 52(2), 142-177. https://doi.org/10.1016/j.intacc.2017.04.002

ElKelish, W. W., \& Hassan, M. K. (2014). Organizational culture and corporate risk disclosure: An empirical investigation for United Arab Emirates listed companies. International Journal of Commerce and Management, 24(4), 279-299. https://doi.org/10.1108/IJCoMA-06-2012-0035

Elzahar, H., \& Hussainey, K. (2012). Determinants of narrative risk disclosures in UK interim reports. The Journal of Risk Finance, 13(2), 133-147. https://doi.org/10.1108/15265941211203189

Gujarati, N. D., \& Porter, C. P. (2012). Basic Econometrics (5th ed.). McGraw Hill.

Ibrahim, A. H., \& Hanefah, M. M. (2016). Board diversity and corporate social responsibility in Jordan. Journal of Financial Reporting and Accounting, 14(2), 279-298. https://doi.org/10.1108/JFRA-06-2015-0065

Iliev, P., \& Roth, L. (2018). Learning from directors' foreign board experiences. Journal of Corporate Finance, 51, 1-19. https://doi.org/10.1016/j.jcorpfin.2018.04.004

Ivers, M. (1991). The random house guide to good writing. New York: Random House. Jensen.

Jackson, A. (2017). Do Foreign Directors Mitigate Earnings Management? Evidence from China. International Journal of Accounting, 52(2), 142-177. https://doi.org/10.1016/j.intacc.2017.04.002

Khan, H. U. Z. (2010). The effect of corporate governance elements on corporate social responsibility (CSR) reporting: Empirical evidence from private commercial banks of Bangladesh. International Journal of Law and Management, 52(2), 82-109. https://doi.org/10.1108/17542431011029406

Konishi, N., \& Ali, M. M. (2007). Risk reporting of Japanese companies and its association with corporate characteristics. International Journal of Accounting, Auditing and Performance Evaluation, 4(3), $263-285$. https://doi.org/10.1504/IJAAPE.2007.016281

Li, Y., He, J., \& Xiao, M. (2018). Risk disclosure in annual reports and corporate investment efficiency. International Review of Economics \& Finance. https://doi.org/10.1016/j.iref.2018.08.021

Linsley, P. M., \& Shrives, P. J. (2006). Risk reporting: A study of risk disclosures in the annual reports of UK companies. British Accounting Review, 38(4), 387-404. https://doi.org/10.1016/j.bar.2006.05.002

Makhlouf, M. H., Al-Sufy, F. J., \&Almubaideen, H. (2018). Board diversity and accounting conservatism: Evidence from Jordan. International Business Research, 11(7), 130-141. https://doi.org/10.5539/ibr.v11n7p130

Marston, C. L., \& Shrives, P. J. (1991). The use of disclosure indices in accounting research: a review article. British Accounting Review, 23(3), 195-210. https://doi.org/10.1016/0890-8389(91)90080-L

Masulis, R. W., Wang, C., \& Xie, F. (2012). Globalizing the boardroom-The effects of foreign directors on corporate governance and firm performance. Journal of Accounting and Economics, 53(3), 527-554. https://doi.org/10.1016/j.jacceco.2011.12.003

Miletkov, M., Poulsen, A., \& Wintoki, M. B. (2017). Foreign independent directors and the quality of legal institutions. Journal of International Business Studies, $48(2)$, $267-292$. https://doi.org/10.1057/s41267-016-0033-0

Mokhtar, E. S., \& Mellett, H. (2013). Competition, corporate governance, ownership structure and risk reporting. Managerial Auditing Journal, 28(9), 838-865. https://doi.org/10.1108/MAJ-11-2012-0776

Moumen, N., Ben Othman, H., \& Hussainey, K. (2016). Board structure and the in formativeness of risk disclosure: Evidence from MENA emerging markets. Advances in Accounting, 35, 82-97. https://doi.org/10.1016/j.adiac.2016.09.001

Oxelheim, L., \& Randøy, T. (2003). The impact of foreign board membership on firm value. Journal of Banking \& Finance, 27(12), 2369-2392. https://doi.org/10.1016/S0378-4266(02)00395-3 
Rajab, B., \& Handley-Schachler, M. (2009). Corporate risk disclosure by UK firms: trends and determinants. World Review of Entrepreneurship, Management and Sustainable Development, 5(3), 224-243. https://doi.org/10.1504/WREMSD.2009.026801

Tsang, A., Xie, F., \& Xin, X. (2019). Foreign institutional investors and corporate voluntary disclosure around the World. The Accounting Review. https://doi.org/10.2308/accr-52353

Uddin, M. H., \& Hassan, M. K. (2011). Corporate risk information in annual reports and stock price behavior in the United Arab Emirates. Academy of Accounting and Financial Studies, 15(1), 59-84.

Wu, M. W., Shen, C. H., \& Lu, C. H. (2015). Do more foreign strategic investors and more directors improve the earnings smoothing? The case of China. International Review of Economics \& Finance, 36, 3-16. https://doi.org/10.1016/j.iref.2014.11.003

Zeghal, D., \& Aoun, M. El. (2016). The effect of the 2007/2008 Financial Crisis on enterprise risk management disclosure of Top US Banks. Journal of Modern Accounting and Auditing, 12(1), 28-51. https://doi.org/10.17265/1548-6583/2016.01.003

\section{Appendix}

Appendix A: Risk disclosure categories adopted from Linsley and Shrives (2006)

\section{Financial risk}

- Interest rate

- Exchange rate

- Commodity

- Liquidity

- $\quad$ Credit

\section{Operations Risk}

- Customer Satisfaction

- Product Development

- Efficiency and Performance

- Sourcing

- Stock Obsolescence and Shrinkage

- Product and Service Failure

- Environmental

- Health and Safety

- Brand Name Erosion

Empowerment Risk

- Leadership And Management

- Outsourcing

- Performance Incentives

- Change Readiness

- Communications

Information Processing and Technology Risk

- Integrity

- Access

- Availability 
- Infrastructure

\section{Integrity Risk}

- Management and Employee Fraud

- Illegal Acts

- Reputation

\section{Strategic Risk}

- Environmental Scan

- Industry

- Business Portfolio

- Competitors

- Pricing

- Valuation

- Planning

- Life Cycle

- Performance Measurement

- Regulatory

- $\quad$ Sovereign and Political

Appendix B: Decision rules for risk disclosures

- To identify risk disclosures a broad definition of risk is to be adopted as explained below.

- Sentences are to be coded as risk disclosures if the reader is informed of any opportunity or prospect, or of any hazard, danger, harm, threat or exposure, that has already impacted upon the company or may impact upon the company in the future or of the management of any such opportunity, prospect, hazard, harm, threat or exposure.

- Although the definition of risk is broad, disclosures must be specifically stated; they cannot be implied.

- The risk disclosures shall be classified into the categories in the Appendix A.

- If a sentence has more than one possible classification, the information will be classified into the category that is most emphasised within the sentence.

- Any disclosure that is repeated shall be recorded as a risk disclosure sentence each time it is discussed. If a disclosure is too vague in its reference to risk, then it shall not be recorded as a risk disclosure. 